\title{
The growth dynamics in Brachiaria species according to nitrogen dose and shade $^{1}$
}

\section{Domingos Sávio Campos Paciullo², Priscila Beligoli Fernandes ${ }^{3}$, Carlos Augusto de Miranda Gomide $^{2}$, Carlos Renato Tavares de Castro², Fausto de Souza Sobrinho², Carlos Augusto Brandão de Carvalho ${ }^{4}$}

\footnotetext{
1 Projeto financiado pela FAPEMIG.

2 Embrapa Gado de Leite - Rua Eugênio do Nascimento, 610 - Dom Bosco - 36038-330 - Juiz de Fora, MG.

${ }^{3}$ Universidade Presidente Antônio Carlos (Unipac) - Estagiária Embrapa Gado de Leite.

${ }^{4}$ Universidade Federal Rural do Rio de Janeiro - Instituto de Zootecnia.
}

ABSTRACT - It was studied the effects of shading (0, 36 and 54\%) and of four nitrogen doses $(0,50,100$ and $150 \mathrm{mg} \mathrm{N} / \mathrm{dm}^{3}$ of soil) on the morphogenetic traits and on the tillering of grasses of Brachiaria genus (B. decumbens, B. ruziziensis and $B$. brizantha cv. Marandu and cv. Xaraes), cultivated in pots with $5 \mathrm{~kg}$ substrate. It was used a complete random design, in a $3 \times 4 \times 4$ factorial scheme with three replications. Nitrogen promoted increase in leaf appearance rate and in average leaf blade length, whereas shading increased stem elongation rate. Leaf elongation rate and tillering varied with the interaction among shading percentages and nitrogen doses. Shading increased response efficiency of leaf elongation rate to nitrogen doses, but reduced for tillering, evidencing priority existing tillering growth in detriment to appearance of new tillers when there is light restriction for the plants. Phenotypic adjustments, in response to light reduction, indicate that the studied grasses present tolerance to moderate shading.

Key Words: Brachiaria brizantha, Brachiaria decumbens, Brachiaria ruziziensis, morphogenesis, silvopastoral system, tillering

\section{Dinâmica do crescimento de espécies de braquiária de acordo com a dose de nitrogênio e o sombreamento}

\begin{abstract}
RESUMO - Estudaram-se os efeitos do sombreamento (0, 36 e 54\%) e de doses de nitrogênio (0, 50, 100 e $150 \mathrm{mg} / \mathrm{dm}^{3}$ de solo) nas características morfogênicas e no perfilhamento de gramíneas do gênero Brachiaria (B. decumbens, B. ruziziensis e $B$. brizantha cvs. Marandu e Xaraes) cultivadas em vasos com capacidade para $5 \mathrm{~kg}$ de substrato. Adotou-se o delineamento inteiramente casualizado, em esquema fatorial $3 \times 4 \times 4$ com três repetições. O nitrogênio promoveu aumento na taxa de aparecimento de folhas e no comprimento médio das lâminas foliares, enquanto o sombreamento aumentou a taxa de alongamento do colmo. A taxa de alongamento de folhas e o perfilhamento variaram com a interação entre as percentagens de sombra e as doses de nitrogênio. O sombreamento aumentou a eficiência de resposta da taxa de alongamento de folhas às doses de nitrogênio, mas reduziu para o perfilhamento, evidenciando prioridade no crescimento de perfilhos existentes em detrimento do surgimento de novos perfilhos quando há restrição de luminosidade para as plantas. Os ajustes fenotípicos, em resposta à diminuição de luz, indicam que as forrageiras estudadas apresentam tolerância ao sombreamento moderado.
\end{abstract}

Palavras-chave: Brachiaria brizantha, Brachiaria decumbens, Brachiaria ruziziensis, morfogênese, perfilhamento, sistema silvipastoril

\section{Introduction}

The use of silvopastoral systems has been suggested to ensure sustainability in animal production systems because of their potential to increase soil fertility, to improve forage quality, to promote animal thermal comfort and to provide income diversification for the producer
(Carvalho et al., 2007; Porfírio-da-Silva, 2007). However, trees reduce the light available for the grass, affecting the morphogenetic properties that determine its productivity (Paciullo et al., 2008). The response to shading depends on the forage species, on the level of shading, and on soil fertility, especially nitrogen availability (Rozados-Lorenzo et al., 2007; Sousa et al., 2007; Guenni et al., 2008; Soares et al., 2009). 
Grass tolerance to shade depends on the ability of the grass to adapt, morphologically and physiologically, to a particular level of irradiance (Dias-Filho, 2000). Under conditions of moderate shade, grasses can continue to grow at levels considered to be satisfactory (Paciullo et al., 2007; Guenni et al., 2008; Soares et al., 2009), with an increase in the ratio of above-ground biomass to root biomass (Wilson, 1998; Dias-Filho, 2000; Guenni et al., 2008), in the specific leaf area (Dias-Filho, 2000; Paciullo et al., 2007; Guenni et al., 2008), in the leaf elongation rate and leaf length (Dias-Filho, 2000; Paciullo et al., 2008) and a reduction in the tillering rate (Gautier et al., 1999; Paciullo et al., 2007).

According to Wilson (1996), soil humidity levels drop more slowly in shaded soil than in soil in full sunlight, which enhance microbial activity in the leaf litter, leading to a greater mineralization and nitrogen availability in the soil, resulting in the greater pasture dry matter production (Paciullo et al., 2007; Guenni et al., 2008).

However, even grasses fairly tolerant to shade show a reduction in forage production under intense shade, especially when the level of shade exceeds $50 \%$ of the incident radiation (Andrade et al., 2004; Paciullo et al., 2007; Soares et al., 2009; Garcez Neto et al., 2010). These results suggest that pasture growth in silvopastoral systems depends on the interaction between shade and soil fertility.

The objective of the present study was to evaluate the effects of shade and nitrogen dose on the morphogenetic characteristics and tillering of four grasses of the Brachiaria genus.

\section{Material and Methods}

The experiment was carried out at the Embrapa Gado de Leite, in Juiz de Fora, Minas Gerais located at 21 $41^{\circ}$ ' 20" S, $43^{\circ} 20^{\prime} 40^{\prime \prime} \mathrm{W}$ and $678 \mathrm{~m}$ mean altitude. The Köppen classification for the regional climate is type Cwa (mesothermal).

Seeds of Brachiaria brizantha (Hochst. ex. A. Rich) Stapf cvs. Marandu and Xaraes, B. decumbens cv. Basilisk and Common B. ruziziensis cv. were planted in plastic pots containing commercial substrate based on Pinus spp. After 20 days of growth, the seedlings were transplanted to tubes with a volume of $35 \mathrm{~cm}^{3}$ containing the same commercial substrate. After 40 days, three seedlings from each genotype were transplanted to plastic pots containing $5.0 \mathrm{~kg}$ of a mixture of soil (Red-Yellow Latosol) and sand, in a 3:1 ratio. Limestone was added at $2 \mathrm{t} / \mathrm{ha}$ to give a substrate with the following chemical composition: phosphorous (Mehlich-1) = $4.4 \mathrm{mg} / \mathrm{dm}^{3} ;$ potassium $=47 \mathrm{mg} / \mathrm{dm}^{3}$; calcium $=0.8 \mathrm{cmolc} / \mathrm{dm}^{3}$; magnesium $=0.3 \mathrm{cmolc} / \mathrm{dm}^{3} ; \mathrm{H}+\mathrm{Al}=1.82 \mathrm{cmolc} / \mathrm{dm}^{3}$; base saturation $=40 \%$; and $\mathrm{pH}\left(\mathrm{H}_{2} \mathrm{O}\right)=6.3$.

The experimental design was completely randomised in a factorial scheme with three replications, consisting of four grasses subjected to three levels of artificial shading $(0,36$, and $54 \%$ ) and four doses of nitrogen ( $0,50,100$, and $150 \mathrm{mg}$ $\mathrm{N} / \mathrm{dm}^{3}$ of soil). Shading was achieved by using polypropylene shading cloth of different transparency, fixed on supports $2 \mathrm{~m}$ above the workbenches with the pots. Shading cloth was also placed on the sides to prevent morning and afternoon sun light incidence. Shading percentages were calculated by measuring the photosynthetically active radiation in the full sunlight and under the shade condition. A Decagon brand, LP 80 model, ceptometer was used to read the incident radiation between 11:00 a.m. and 2:00 p.m., in each light environment.

Nitrogen was applied to the soil surface of the pots using urea diluted in water at the rate of $50 \mathrm{~mL}$ per pot per application. At the start of each regrowth period, potassium and phosphorous, as $\mathrm{K}_{2} \mathrm{O}$ and $\mathrm{P}_{2} \mathrm{O}_{5}$, respectively, both at a dose of $50 \mathrm{mg} / \mathrm{dm}^{3}$, were applied together in the nitrogen solution in a single dose. The pots were watered daily to keep the soil moist.

The plants were subjected to the light regimes on March 10, 2008. The morphogenesis study was conducted over two consecutive growth periods: the first from March 10 to April 4, 2008, when the plants were first harvested, and the second from the day of the first harvest to May 19, 2008 (last harvest).

The leaf blades and the stems of a tiller in each pot were measured each week. The full length of the leaf blade was measured, until ligule exposure. The length of emerging blades was measured from the tip to the ligule of the last expanded leaf, up to the point where its ligule was visible. The date that a leaf appeared was defined as the day when its ligule was first observed, and the date of its death, as the day when all of its tissue was senescent (Gomide et al., 2006; Paciullo et al., 2008). Stem length of the stem was measured at the beginning and the end of each evaluation period, as the distance from the soil to the ligule of the youngest adult leaf.

This data was used to estimate the leaf appearance rate and the leaf and stem elongation rates for each tiller. The total number of leaves per tiller was also determined. Leaf lifespan was estimated from the values for leaf appearance rate and the number of leaves per tiller (Chapman \& Lemaire, 1993). Leaf and stem elongation rates were obtained by dividing the difference between the final and initial total lengths of the leaf blades or stem by the number of days in plant growth period. Leaf appearance rate was calculated by dividing the number 
to fully expanded leaves (exposed ligule) that had appeared per tiller by the number of days taken.

The number of tillers per pot was counted at the end of each growth period, before the plants were harvested.

The data (mean for the two growth periods) were subjected to analysis of variance, considering the effects of species, nitrogen doses, and shading levels. Whenever the analysis indicated a significant effect for the nitrogen dose, the data were subjected to regression analysis. When the three shading percentages were evaluated, a mean test (Tukey test at 5\% probability) was applied whenever the variance analysis suggested statistical significance for this variable.

\section{Results and Discussion}

Leaf elongation rate varied with the type of grass $(\mathrm{P}=0.0108)$ and with the interaction between shading percentage and nitrogen dose $(\mathrm{P}=0.0387)$ (Figure 1$)$. Amongst the grasses, the highest mean rate was observed for Xaraes cultivar ( $20.5 \mathrm{~mm} /$ tiller.day) and the lowest for Ruziziensis (16.6 mm/tiller.day), while intermediate, similar values were obtained for $B$. decumbens and Marandu cultivar (18.8 and $19.4 \mathrm{~mm} /$ tiller.day, respectively).

Leaf elongation rate increased linearly with nitrogen dose, confirming the results found in the literature (Garcez Neto, 2002; Alexandrino et al., 2004; Fagundes et al., 2006).

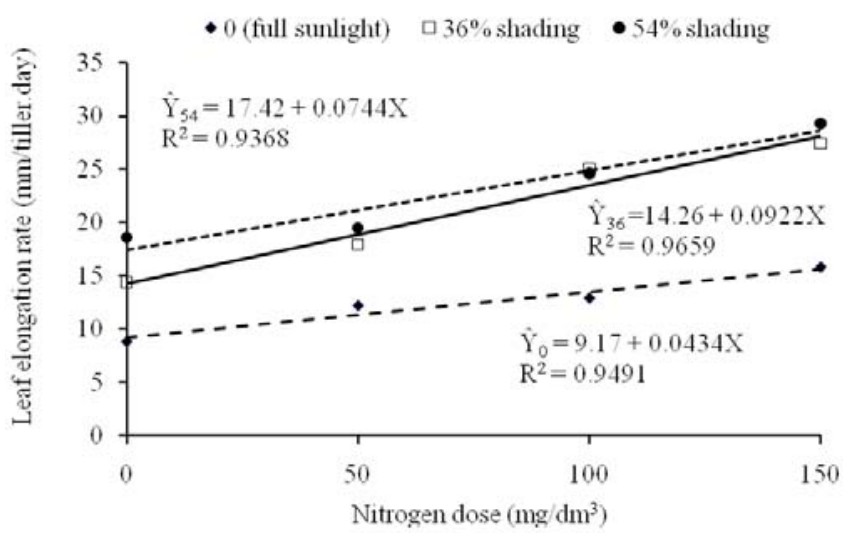

Figure 1 - Leaf elongation rate of Brachiaria species, according to nitrogen dose and shade level.
The rates obtained under shading conditions were always higher than those in full sunlight. There was a difference only between the two greatest degrees of shading (36 and $54 \%$ ) when nitrogen was not applied; the values were similar for doses of $50 \mathrm{~m} / \mathrm{dm}^{3}$ of $\mathrm{N}$ and above (Figure 1).

In full sunlight, each milligram of nitrogen applied resulted in an increase in the leaf elongation rate of $0.04 \mathrm{~mm} /$ tiller.day, while under shading conditions, the increase values were 0.09 and $0.07 \mathrm{~mm} /$ tiller.day for each milligram of nitrogen at levels of 36 and 54\% shading, respectively. Under shading conditions, the plants prioritise the formation of leaf area to the detriment of other fractions, which usually results in higher leaf elongation rate and a larger leaf area in shaded plants (Dias-Filho, 2000; Paciullo et al., 2008; Guenni et al., 2008). The most efficient response to the application of nitrogen highlights how grasses prioritise leaf formation when shaded so as to capture more light.

Stem elongation rate was only influenced $(\mathrm{P}=0.0059)$ by the interaction grass $\times$ shading level (Table 1 ). Whereas no differences were observed between the cultivars in full sunlight, under shading, the grasses $B$. decumbens and $B$. ruziziensis had a higher stem elongation rate than the other two grasses. Shading stimulated the stem elongation rate for all of the grasses except Xaraes, for which no difference was found for the distinct percentages of shade, although the rate was two-fold as high in a higher level of shade. The high coefficient of variation observed (71.7\%) for this variable, associated with the amplitude of the data may have contributed to this result. In field tests with Marandu grass, Gomide et al. (2009) found a coefficient of variation of $87.1 \%$ for stem elongation rate, higher than for the other morphogenic characteristics studied.

More pronounced stem growth is a normal tendency in plants cultivated under shade and is a strategy to compensate for the reduction in light (Castro et al., 1999; Paciullo et al., 2008). Etiolation or whitening of plants subjected to shading is a mechanism by which the plant searches for light by lifting its leaves towards the canopy. In grasses, this mechanism also permits a better distribution of radiation from the canopy along the tiller (Mello \& Pedreira, 2004).

Table 1 - Stem elongation rate (mm/tiller.day), according to grass and shade level

\begin{tabular}{ccccc}
\hline Shading (\%) & \multicolumn{4}{c}{ Grass } \\
\cline { 2 - 5 } & B. decumbens & B. ruziziensis & B. brizantha cv. Marandu & B. brizantha cv. Xaraes \\
\hline 0 & $1.2 \mathrm{bA}$ & $2.1 \mathrm{cA}$ & $0.6 \mathrm{bA}$ & $0.8 \mathrm{aA}$ \\
36 & $3.6 \mathrm{aA}$ & $3.8 \mathrm{bA}$ & $1.1 \mathrm{bB}$ & $0.8 \mathrm{aB}$ \\
54 & $4.8 \mathrm{aA}$ & $6.5 \mathrm{aA}$ & $2.0 \mathrm{aB}$ & $1.6 \mathrm{aB}$ \\
\hline
\end{tabular}

Means followed by different letters, capital letters in lines and small letters in rows, differ $(\mathrm{P}<0.05)$ by Tukey test. Coefficient of variation $(\%)=71.7$. 
Leaf appearance rate varied with the type of grass $(\mathrm{P}<0.0001)$. Xaraes cultivar showed a lower rate $(0.035$ leaf/ tiller.day) than the others, which showed similar values (mean value of 0.083 leaf/tiller.day). The lower leaf appearance rate for Xaraes, associated with its greater leaf elongation rate, is in agreement with the literature, as there is a negative relationship between appearance rate and leaf elongation rate (Grant et al., 1981).

Leaf appearance rate was also influenced $(\mathrm{P}=0.0489)$ by the nitrogen dose (Figure 2), following a quadratic effect, as it was also observed by Garcez Neto et al. (2002). The function of nitrogen on the appearance rate can be analysed as the result of a combination of factors, including the elongation duration and the leaf elongation rate (Robson et al., 1988). The leaf blade elongation rates increased under shade. This fact, associated with the similarity in the appearance rates under the shading conditions, suggests increases in the leaf elongation duration. The length of the pseudostem, determining the path to be travelled by the expanding leaf, appears to be the determining factor for leaf length (Skinner \& Nelson, 1994).

Leaf lifespan was influenced by the grass $\times$ nitrogen dose interaction ( $P=0.0292$ ) (Figure 3$)$. Nitrogen had no influence $(\mathrm{P}>0.05)$ on $\mathrm{B}$. ruziziensis, whereas for other grasses the leaf lifespan decreased $(\mathrm{P}<0.05)$ as the nitrogen dose increased (Figure 3). This result contradicts those of Garcez Neto et al. (2002) and Oliveira et al. (2007), who found

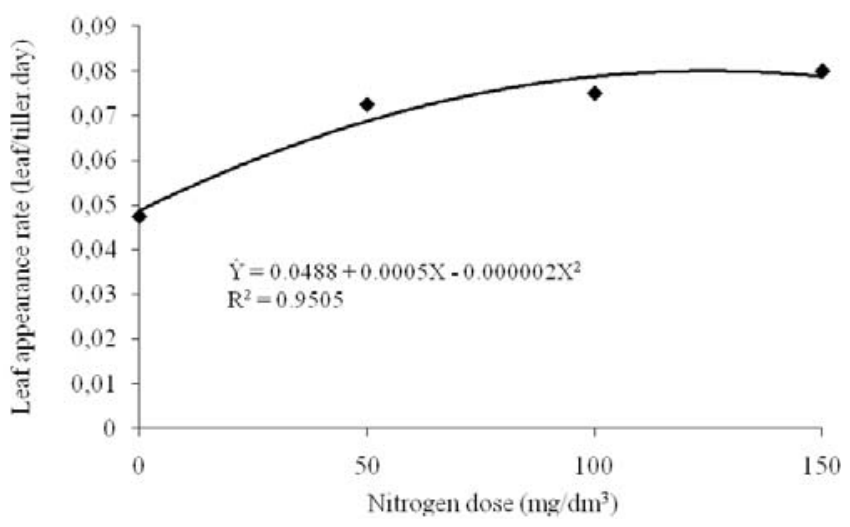

Figure 2 - Leaf appearance rate of Brachiaria species, according to nitrogen dose. that leaf lifespan increased with nitrogen fertilisation. According to these authors, the mechanism by which nitrogen increases leaf lifespan may be associated with the prolongation of the photosynthetic capacity without significant internal remobilisation of the nitrogen in the older leaves. On the other hand, the increase in the nitrogen dose could promote precocity on the plants, increasing leaf senescence in the tillers (Alexandrino et al., 2004) and contributing to the reduction in leaf lifespan, which would explain the results presented here. The reduction in leaf lifespan in response to the nitrogen dose may also be explained by the inverse relationship between the leaf appearance rate and lifespan, in accordance with the lifespan calculation suggested by Chapman \& Lemaire (1993), being used in this study (lifespan is equal to the ratio of the number of leaves per tiller and the leaf appearance rate). Therefore, the increase in leaf appearance rate in response to the application of nitrogen (Figure 2), without a change in the mean number of leaves per tiller was associated with a reduction in the leaf lifespan.

Leaf blade length was influenced by the grass $x$ percentage shading interaction $(\mathrm{P}=0.016)$. Leaves growing under shade were always longer than those in full sunlight, regardless of the cultivar (Table 2), which is consistent with the higher leaf elongation rate in response to the nitrogen dose. Amongst the grasses, Xaraes cultivar had the longest blades, which is consistent with its higher elongation rates

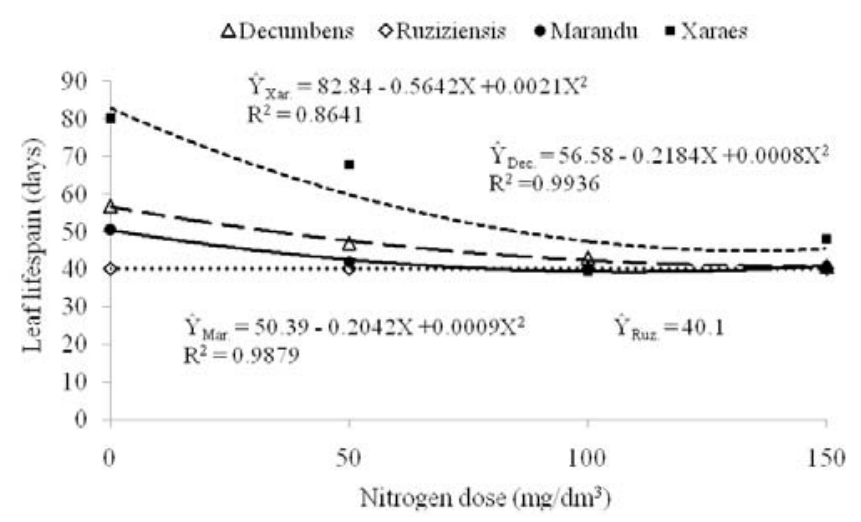

Figure 3 - Leaf lifespan of Brachiaria species, according to nitrogen dose.

Table 2 - Leaf blade length $(\mathrm{cm})$ of Brachiaria species, according to shade level

\begin{tabular}{ccccc}
\hline Shading (\%) & \multicolumn{4}{c}{ Grass } \\
\cline { 2 - 5 } & B. decumbens & B. ruziziensis & B. brizantha cv. Marandu & B. brizantha cv. Xaraes \\
\hline 0 & $15.1 \mathrm{bB}$ & $14.7 \mathrm{bB}$ & $18.9 \mathrm{bB}$ & $24.7 \mathrm{bA}$ \\
36 & $25.7 \mathrm{aC}$ & $25.3 \mathrm{aC}$ & $33.4 \mathrm{aB}$ & $43.3 \mathrm{aA}$ \\
54 & $27.7 \mathrm{aC}$ & $25.4 \mathrm{aC}$ & $35.5 \mathrm{aB}$ & $44.4 \mathrm{aA}$ \\
\hline
\end{tabular}

Means followed by different letters, capital letters in lines and small letters in rows, are different $(\mathrm{P}<0.05)$ by Tukey test. Coefficient of variation $(\%)=17.5$. 
and lower leaf appearance rates, in comparison with the other cultivars. The species $B$. decumbens and $B$. ruziziensis had shorter leaf blades than $B$. brizantha cultivars, except for the leaves produced in full sunlight, under which condition Marandu cultivar produced leaves of a size similar to the first two species mentioned.

Leaf blade length increased quadratically $(\mathrm{P}<0.0001)$ with the nitrogen dose, to a maximum value of $31.1 \mathrm{~cm}$, obtained with a nitrogen dose of $134.3 \mathrm{mg} / \mathrm{dm}^{3}$ (Figure 4). The positive impact of nitrogen on leaf blade length for forage grasses was reported by other authors (Garcez Neto et al., 2002; Fagundes et al., 2006). Nitrogen enables an increase in leaf elongation rate, as found in the present study, by stimulating the production of new cells, which is the means by which the leaf blade changes its size (Garcez Neto et al., 2002). In fact, some studies have indicated a positive correlation between the elongation rate and the leaf blade length (Mazzanti et al., 1994; Garcez Neto et al., 2002).

The mean number of leaves per tiller was not influenced ( $P>0.05)$ by the percentage of shading or the nitrogen dose, but it did vary $(\mathrm{P}<0.0001)$ with the grass cultivar. Extreme values of 3.6 and 4.5 leaves were observed for Xaraes and B. decumbens, respectively. B. ruziziensis and the Marandu cultivar both had a similar intermediate numbers of leaves, 4.3 and 3.9 leaves, respectively.

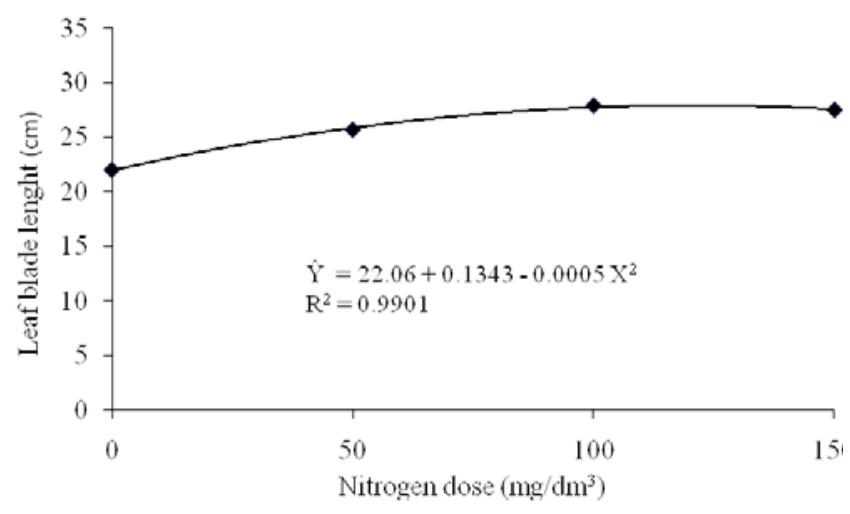

Figure 4 - Leaf blade length of Brachiaria species, according to nitrogen dose.
Tiller density varied with the grass $\times$ percentage shading interaction ( $\mathrm{P}=0.0019)$ (Table 3). Overall, the grasses $B$. decumbens and $B$. ruziziensis had a greater density of tillers than the other grasses. The reduction in the number of tillers/pot when under shade was confirmed; for B. decumbens, only the level of $54 \%$ affected tillering, whereas for the others, shading of $36 \%$ reduced the tiller density. Light is an important factor in the production of new tillers, which is consistent with the results found in this study. The similarity for the values from 0 to $36 \%$ shading indicates that Brachiaria decumbens have greater tolerance to moderate shade, in terms of the appearance of tillers, in comparison with the other grasses, for which a contrast was observed between the full sunlight and under shade values, regardless of light intensity.

It is interesting to note that the lower tiller density in Xaraes cultivar coincides with its lower leaf appearance rate. The leaf appearance rate has a central role in the morphogenesis of grasses inasmuch as it affects the three structural characteristics, which are the following: number of leaves per tiller, leaf size, and tiller population density (Lemaire \& Chapman, 1996). Hence, aside from representing the velocity of photosynthetic tissue formation, the leaf appearance rate also responds to the plant tiller potential (Gomide et al., 2006), since each leaf represents a phytomer (Gomide, 1997) consisting of a shoot able to become a new tiller. In practice, plants with a high tillering capacity occupy more soil space. This aspect increases in importance in silvopastoral systems in which shading reduces tiller density in the pasture (Paciullo et al., 2007; Guenni et al., 2008). Hence, establishing silvopastoral systems with Xaraes cultivar, whose tiller density is naturally lower, can only be recommended with reservations, particularly in mountainous topographic conditions, where there is greater risk of soil erosion.

Tiller density also varied $(\mathrm{P}=0.005)$ with the shading $\times$ nitrogen dose interaction (Figure 5). Under full sunlight conditions, the response was linear; whereas for $36 \%$ and $54 \%$ shading, the responses were quadratic, showing that shading limited the plant response to the applied nitrogen, in terms of the appearance of new tillers. This result

Table 3 - Tiller (number/plot) of Brachiaria species, according to shade level

\begin{tabular}{ccccc}
\hline Shading (\%) & \multicolumn{4}{c}{ Grass } \\
\cline { 2 - 5 } & B. decumbens & B. ruziziensis & B. brizantha cv. Marandu & B. brizantha cv. Xaraes \\
\hline 0 & $30.3 \mathrm{aA}$ & $32.6 \mathrm{aA}$ & $25.2 \mathrm{aB}$ & $21.3 \mathrm{aC}$ \\
36 & $28.6 \mathrm{aA}$ & $24.4 \mathrm{bB}$ & $20.7 \mathrm{bC}$ & $18.1 \mathrm{bC}$ \\
54 & $24.7 \mathrm{bA}$ & $24.5 \mathrm{bA}$ & $17.9 \mathrm{cB}$ & $16.5 \mathrm{bB}$ \\
\hline
\end{tabular}

Means followed by different letters, capital letters in lines and small letters in rows, differ $(\mathrm{P}<0.05)$ by Tukey test. Coefficient of variation $(\%)=11.8$. 


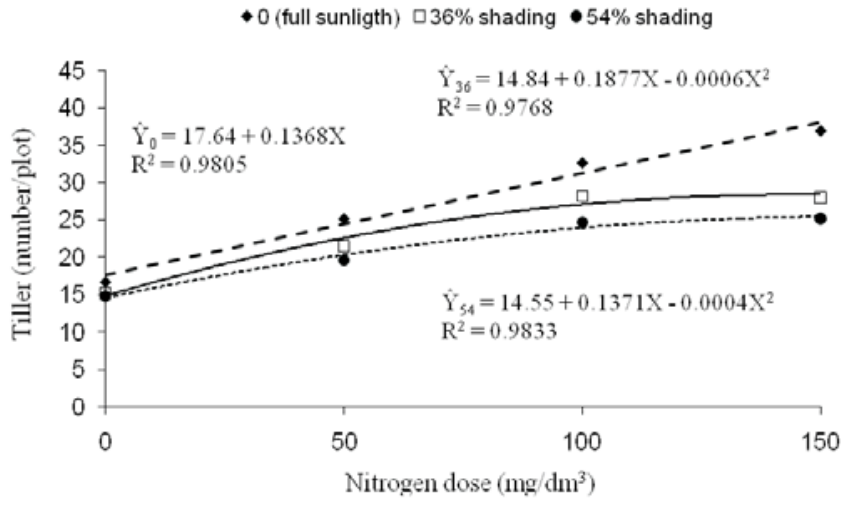

Figure 5 - Tiller number of Brachiaria species, according to nitrogen dose and shade level.

corroborates those in the literature (Gautier, 1999; Andrade et al., 2004; Paciullo et al., 2008) and reinforces the importance of light in the production of new tillers in grass pasture. Joint analysis of the data for the response of the leaf elongation rate and tiller density variables to the nitrogen dose indicates that, under shade, the increase in availability of nitrogen improve the growth of existing tillers by increasing the leaf elongation rate, to the detriment of the production of new tillers.

The reduction in the response to nitrogen dose under artificial shading conditions demonstrates the need for field studies in silvopastoral systems to evaluate fertilization strategies, particularly for grasses with a greater productive capacity used in more intensive production systems.

\section{Conclusions}

Nitrogen improves leaf elongation and leaf appearance rates and the length of the leaf blade. Shading stimulates the response of the plants to the application of nitrogen, in terms of leaf elongation, but reduces tillering. The four grasses of Brachiaria genus show tolerance to moderate shading.

\section{Referências}

ALEXANDRINO, E.; NASCIMENTO JÚNIOR, D.; MOSQUIM, P.R. et al. Características morfogênicas e estruturais na rebrotação da Brachiaria brizantha cv. Marandu, submetida a três doses de nitrogênio. Revista Brasileira de Zootecnia, v.33, p.1372-1379, 2004.

ANDRADE, C.M.S.; VALENTIM, J.F.; CARNEIRO, J.C. et al. Crescimento de gramíneas e leguminosas forrageiras tropicais sob sombreamento. Pesquisa Agropecuária Brasileira, v.39, n.3, p.263-270, 2004.

CARVALHO, M.M.; PACIULLO, D.S.C.; CASTRO, C.R.T. et al. Experiências com SSP's no Bioma Mata Atlântica na Região
Sudeste. In: FERNANDES, E.N.; PACIULLO, D.S.C.; CASTRO, C.R.T. et al. (Eds.) Sistemas agrossilvipastoris na América do Sul: desafios e potencialidades. Juiz de Fora: Embrapa Gado de Leite, 2007. p.105-136.

CASTRO, C.R.T.; GARCIA, R.; CARVALHO, M.M. et al. Produção forrageira de gramíneas cultivadas sob luminosidade reduzida. Revista Brasileira de Zootecnia, v.28, n.5, p.919-927, 1999.

CHAPMAN, D.F.; LEMAIRE, G. Morphogenetic and structural determinants of plant regrowth after defoliation. In: IINTERNATIONAL GRASSLAND CONGRESS, 17., 1993. Proceedings... Australia, 1993. p.95-104.

DIAS-FILHO, M. Growth and biomass allocation of the $\mathrm{C}_{4}$ grasses Brachiaria brizantha and B. humidicola under shade. Pesquisa Agropecuária Brasileira, v.35, n.12, p.2335-2341, 2000.

FAGUNDES, J.L.; FONSECA, D.M.; MISTURA, C. Características morfogênicas e estruturais do capim-braquiária em pastagem adubada com nitrogênio avaliadas nas quatro estações do ano. Revista Brasileira de Zootecnia, v.35, n.1, p.21-29, 2006.

GARCEZ NETO, A.F.; GARCIA, R.; MOOT, D.J. et al. Aclimatação morfológica de forrageiras temperadas a padrões e níveis de sombreamento. Revista Brasileira de Zootecnia, v.39, n.1, p.42-50, 2010.

GARCEZ NETO, A.F.; NASCIMENTO JÚNIOR, D.; REGAZZI, A.J. et al. Respostas morfogênicas e estruturais de Panicum maximum cv. Mombaça sob diferentes níveis de adubação nitrogenada e alturas de corte. Revista Brasileira de Zootecnia, V.31, n.5, p.1890-1900, 2002.

GAUTIER, H.; VARLET-GRANCHER, C.; HAZARD, L. Tillering responses to the light environment and to the defoliation in populations of perennial ryegrass (Lolium perenne L.) selected for contrasting leaf length. Annals of Botany, v.83, p.423-429, 1999.

GOMIDE, C.A.M.; REIS, R.A.; SIMILI, F.F. et al. Caracterização da pastagem de capim-marandu conforme o nível de sua suplementação alimentar e os ciclos de pastejo. Pesquisa Agropecuária Brasileira, v.44, n.5, p.526-533, 2009.

GOMIDE, C.A.M.; GOMIDE, J.A.; PACIULLO, D.S.C. Morfogênese como ferramenta para o manejo de pastagens. Revista Brasileira de Zootecnia, v.35, p.554-579, 2006 (supl. especial).

GOMIDE, J.A. Morfogênese e análise de crescimento de gramíneas tropicais. In: SIMPÓSIO INTERNACIONAL SOBRE PRODUÇÃO ANIMAL EM PASTEJO, 1997, Viçosa, MG. Proceedings... Viçosa, MG: Universidade Federal de Viçosa, 1997. p.411-429.

GRANT, S.A.; BARTHRAM, G.T.; TORVELL, L. Components of regrowth in grazed and cut Lolium perenne swards. Grass and Forage Science, v.36, n.3, p.155-168, 1981.

GUENNI, O.; SEITER, S.; FIGUEROA, R. Growth responses of three Brachiaria species to light intensity and nitrogen supply. Tropical Grasslands, v.42, p.75-87, 2008.

LEMAIRE, G.; CHAPMAN, D. Tissue flows in grazed plant comumunities. In: HODGSON, J.; ILLIUS, A.W. (Eds.). The ecology and management of grazing systems. Wallingford: CAB International, 1996. p.3-36.

MAZZANTI, A.; LEMAIRE, G.; GASTAL, F. Effect of nitrogen fertilization upon herbage production of a Tall fescue sward continuously grazed by sheep. 1) Herbage growth dynamics. Grass and Forage Science, v.49, n.3, p.111-120, 1994.

MELLO, A.C.L.; PEDREIRA, C.G.S. Respostas morfológicas do capim-tanzânia (Panicum maximum Jacq. cv. Tanzânia-1) irrigado à intensidade de desfolha sob lotação rotacionada. Revista Brasileira de Zootecnia, v.33, n.2, p.282-289, 2004.

OLIVEIRA, A.B.; PIRES, A.J.V.; NETO, U.M. et al. Morfogênese do capim-tanzânia submetido a adubações e intensidades de corte. Revista Brasileira de Zootecnia, v.36, n.4, p.1006-1013, 2007.

PACIULLO, D.S.C.; CAMPOS, N.R.; GOMIDE, C.A.M. et al. Crescimento do pasto de capim-braquiária influenciado pelo nível de sombreamento e pela a estação do ano. Pesquisa Agropecuária Brasileira, v.43, n.7, p.317-323, 2008. 
PACIULlO, D.S.C.; CARVALHO, C.A.B.; AROEIRA, L.J.M. et al. Morfofisiologia e valor nutritivo do capim-braquiária sob sombreamento natural e a sol pleno. Pesquisa Agropecuária Brasileira, v.42, n.4, p.573-579, 2007.

PORFÍRIO-DA-SILVA, W. Ecologia e manejo em sistema silvipastoril. In: FERNANDES, E.N.; PACIULLO, D.S.C.; CASTRO, C.R.T. et al. (Eds.) Sistemas agrossilvipastoris na América do Sul: desafios e potencialidades. Juiz de Fora: Embrapa Gado de Leite, 2007. p.51-68.

ROBSON, M.J.; RYLE, G.J.A.; WOLEDGE, J. The grass plant - its form and function. In: JONES, M.B.; LAZENBY, A. (Eds.). The grass crop: the physiological basis of production. London: Chapman \& Hall, 1988. p.25-83.

ROZADOS-LORENZO, M.J.; GONZALEZ-HERNANDEZ, M.P.; SILVA-PANDO, F.J. Pasture production under different tree species and densities in an Atlantic silvopastoral system. Agroforestry System, v.70, p.53-62, 2007.
SKINNER, R.H.; NELSON, C.J. Role of leaf appearance rate and coleoptile tiller in regulating tiller production. Crop Science, v.34, n.1, p.71-75, 1994.

SOARES, A.B.; SARTOR, L.R.; ADAMI, P.F. et al. Influência da luminosidade no comportamento de onze espécies forrageiras perenes de verão. Revista Brasileira de Zootecnia, v.38, n.2, p.443-451, 2009.

SOUSA, L.F.; MAURÍCIO, R.M.; GONÇALVES, L.C. et al. Produtividade e valor nutritivo da Brachiaria brizantha cv. Marandu em um sistema silvipastoril. Arquivo Brasileiro de Medicina Veterinária e Zootecnia, v.59, n.4, 1029-1037, 2007.

WILSON, J.R. Influence of planting four tree species on the yield and soil water status of green panic pasture in subhumid southeast Queensland. Tropical Grassland, v.32, p.209-220, 1998.

WILSON, J.R. Shade-stimulated growth and nitrogen uptake by pasture grasses in a subtropical environment. Australian Journal of Agriculture Research, v.47, p.1075-1093, 1996. 